\title{
Competence as a Factor of Emotional Capital
}

\author{
Irina Ivanova, Deniss Sceulovs \\ Riga Technical University, Faculty of Engineering Economics and Management, \\ Department of Engineering Economics and Management \\ Contactpoint. Address: Kalnciema street 1, Rīga LV-11048, Latvija.
}

\begin{abstract}
Use of modern knowledge and technologies determines market development which grows with high rates. Today's business environment cause changes that affect the formation of the modern technologies, including business models, which generates changes not only the competencies, but I soft skills, including emotional capital, as a factor influencing the development of modern companies. Article investigates configuration during company growth process. Researching relevance and justification, the purpose of work is conception of factors, which positively influenced development of the entity, organization developments influencing on the productive direction.

The aim of the article is to provide the competence concept and its components to identify interrelationship with knowledge and skills which is related to emotional intelligence as a part of emotional capital. And as the result, the emotional equity as element of competence, acting as the regulator, carries out a role of positive feedback within strategic management.
\end{abstract}

\section{Keywords: emotional capital, competence, resource, emotional intelligence.}

\section{INTRODUCTION}

The question of the value of competences and their formation is one of the ways to study factors required to create a set of competencies that is associated with the efficiency of the organization. The company's ability to compete and be resilient to changes in the external environment in the modern practice of entrepreneurship focuses on strengthening the elements of competencies which may include a combination of key competencies skills, abilities, technologies, allowing the company to provide its consumers with certain values [1].

In this paper we consider the notion of competence and identify factors of emotional capital as the basis of forming a framework of competencies for effective development of the organization and the achievement of related goals.

As result of literature review it is necessary to indicate that a different definition or understanding of the meaning of competence, use different classifications of the set of competencies its define for scientific and practical purposes, and to determine their use and significance in connection with the concept of emotional capital. According to research out the basic set, which includes elements such as knowledge, skills and abilities, and it is also necessary to determine the readiness of the application of these elements, which are interconnected with the concept of emotional capital.

The object of research is competence and its elements.
The subject of research is interaction of competence elements such as knowledge, skill and capabilities.

The methodology: literature overview comprising and interpretation.

Exploring sources consider the meanings and elements of competencies in various fields related to management, social sciences and human resources.

\section{II.MATERIALS AND METHODS}

General definition of competence is often cited from David McClelland as the founder of the modern competences movement. In his paper "Testing for competence rather than for intelligence" McClelland (1973) introduced the concept of "competency" to replace the more limited concept of "skill" and also include behavioural aspects and technical capabilities.

The linguistic roots of the word competence come from Latin "competens" - as being able and allowed by law/regulation, and "competentia" as capability and permission. The use of the West European words "competence" and "competency" dates back to the early 16th century. The same word competence can be found also in ancient Greek - "ikanotis". It is translated as the quality of being "ikanos" (capable), having the ability to achieve something; a skill. "Epangelmatikes ikanotita stands for stands for professional/vocational capability or competence. (Mulder, 2007)[2].

The widely accepted definition of the competency model used by managers of Anglo-Saxon countries is 
the set of desired competencies - skills, knowledge, attitudes, underlying characteristics or behaviour that differentiate effective performers from ineffective ones (Boyatzis, 1982; McLagan, 1996). Moreover, the discussion continues on whether the term "competency" (plural _-"competencies") and "competence" (plural - "competences") bear the same or a different meaning. According to some dictionaries, both concepts have the same meaning while others highlight certain differences. Supporters of the latter approach claim that "competency" concentrates on how people behave while "competence" focuses on what people do. In addition, "competency" corresponds to behaviour-based aspects whereas "competence" - to skill-based ones (Sanghi, 2007) [2].

Mayer and Salovey (1997), for example, define emotional intelligence as "the ability to perceive emotion, use emotion to facilitate thought, understand emotions, and manage emotion" (p. 3). This is not unlike Kanning (2002), who regards social competence as containing the behavioral control of emotions, meaning the ability to control one's feelings both internally and externally. These incongruities and overlaps necessitate a great deal of effort to find a shared vocabulary. They are a sign that these constructs derive from a common theoretical basis of underlying skill, competence and intelligence dimensions that need to be precisely defined. A "concept clean-up" (Organ, 1997) is needed [3].

The competencies of perception, understanding, utilizing and managing emotions effectively in the self and others comprise the core of emotional intelligence (Maul, 2012; Mayer, Salovey \& Caruso, 2004; 2008). Competency in perception of emotion involves recognizing emotion-related facial and voice cues of others and awareness of one's own body states relating to emotion. Competency in understanding one's own and others' emotions consists of knowing the causes and consequences of different emotions as well as being able to differentiate between varying emotions. Utilizing emotions involves harnessing the effects of emotions, for example by drawing on positive mood to enhance creative thought [4].

Emotional intelligence consists of adaptive emotional functioning involving inter-related competencies relating to perception, understanding, utilizing and managing emotions in the self and others. Researchers in diverse fields have studied emotional intelligence and found the construct to be associated with a variety of intrapersonal and interpersonal factors such as mental health, relationship satisfaction, and work performance. This article reviews research investigating the impact of training in emotional-intelligence skills. The results indicate that it is possible to increase emotional intelligence and that such training has the potential to lead to other positive outcomes. The paper offers suggestions about how future research, from diverse disciplines, can uncover what types of training most effectively increase emotional intelligence and produce related beneficial outcomes [4] .

Unfortunately, the authors do not reveal the weight of each part of the value of competences, which does not reflect the significance and interaction of emotional capital and talent in general. To form an objective opinion about the value of competencies, in addition to literature overview view, the authors used the research that was done in the framework of the projects and conducted the triangulation.

\section{RESULTS AND DISCUSSION}

Table 1.

Competence Concepts

\begin{tabular}{|c|c|c|c|}
\hline № & Author/Publication title & Concepts & Findings: Keyword \\
\hline 1. & $\begin{array}{l}\text { Leading public service } \\
\text { organizations: how to obtain high } \\
\text { employee self-efficacy and } \\
\text { organizational performance } \\
\text { Christian Bøtcher Lotte Bøgh } \\
\text { Andersen } \\
\text { Political Science, Aarhus } \\
\text { University, Aarhus C, [5] }\end{array}$ & $\begin{array}{l}\text { Competence provide positive feedback on } \\
\text { performance to strengthen feelings, getting } \\
\text { conditional rewards }\end{array}$ & $\begin{array}{l}\text { Positive feedback on } \\
\text { performance }\end{array}$ \\
\hline 2. & $\begin{array}{l}\text { Innovation and international } \\
\text { business } \\
\text { John Cantwell [6] }\end{array}$ & $\begin{array}{l}\text { Competence-creating capabilities - the presence or } \\
\text { absence of local knowledge in either direction. }\end{array}$ & $\begin{array}{l}\text { Competence-creating } \\
\text { capabilities to knowledge }\end{array}$ \\
\hline 3. & $\begin{array}{l}\text { The Roles of Sustainability } \\
\text { Orientation and Market Knowledge } \\
\text { Competence in New Product } \\
\text { Development Success } \\
\text { Marius C. Claudy, Mark Peterson } \\
\text { [7] }\end{array}$ & $\begin{array}{l}\text { competence is an important capability, which helps } \\
\text { firms to balance social and ecological objectives with } \\
\text { economic goals such as profitability and market } \\
\text { share. }\end{array}$ & Capability to balance objectives \\
\hline 4. & $\begin{array}{l}\text { The Core Competence of the } \\
\text { Corporation } \quad \text { C. K. } \\
\begin{array}{l}\text { Prahalad, G. Hamel[1] } \\
\end{array}\end{array}$ & $\begin{array}{l}\text { Core competencies are the organization's collective } \\
\text { learning and ability to coordinate and integrate } \\
\text { multiple production skills and technology streams; } \\
\text { they are also about the organization of work and } \\
\text { delivery of value in services and manufacturing. }\end{array}$ & $\begin{array}{l}\text { Competencies - collective } \\
\text { learning and ability to } \\
\text { coordinate and integrate } \\
\text { multiple production skills }\end{array}$ \\
\hline
\end{tabular}




\begin{tabular}{|c|c|c|c|}
\hline 5. & $\begin{array}{l}\text { Competency modelling targeted on } \\
\text { boosting configuration of virtual } \\
\text { organisations } \\
\text { Ekaterina Ermilova, Hamideh } \\
\text { Afsarmanesh[8] }\end{array}$ & $\begin{array}{l}\text { Formation of Virtual Organizations as the base of } \\
\text { organizations' competencies defined; ‘ } 4 \text { C-model" } \\
\text { (Capabilities + Capacities + Costs + Conspicuities), } \\
\text { developed to comprehensively specify competencies } \\
\text { of VBE member organizations. }\end{array}$ & $\begin{array}{l}\text { Capabilities + Capacities + } \\
\text { Costs + Conspicuities }\end{array}$ \\
\hline 6. & $\begin{array}{l}\text { Handbook of Competence and } \\
\text { Motivation } \\
\text { Andrew J. Elliot, Carol S. Dweck } \\
\text { [9] }\end{array}$ & $\begin{array}{l}\text { Need for competence is mediated, organized, and } \\
\text { satisfied through cognitive processes. These } \\
\text { cognitive processes include beliefs, expectations, and } \\
\text { inferences about competence; schemas or goals } \\
\text { oriented toward acquiring or demonstrating } \\
\text { competence; and beliefs about the importance or } \\
\text { value of different competence domains. }\end{array}$ & $\begin{array}{l}\text { Cognitive processes include } \\
\text { beliefs, expectations, and } \\
\text { inferences about competence }\end{array}$ \\
\hline 7. & $\begin{array}{l}\text { Towards a Competence Theory of } \\
\text { the Firm } \\
\text { Nicolai J. Foss, Christian Knudsen } \\
\text { [10] }\end{array}$ & $\begin{array}{l}\text { By competence - typically idiosyncratic knowledge } \\
\text { capital that allows its holder to perform activities - in } \\
\text { particular, to solve problem in certain ways, and } \\
\text { typically do this more efficiently that others, because } \\
\text { its skill-like character, competence has a large } \\
\text { component and is asymmetrically distributed. }\end{array}$ & $\begin{array}{l}\text { Knowledge capital that allows } \\
\text { its holder to perform activities - } \\
\text { in particular }\end{array}$ \\
\hline 8. & $\begin{array}{l}\text { Personality and intellectual } \\
\text { competence Chamorro- } \\
\text { Premuzic, T; Furnham, A [11] }\end{array}$ & $\begin{array}{l}\text { Personality and Intellectual Competence is an } \\
\text { outstanding account of the relationship between } \\
\text { major individual differences constructs. }\end{array}$ & $\begin{array}{l}\text { Intellectual Competence- the } \\
\text { relationship between major } \\
\text { individual differences } \\
\text { constructs }\end{array}$ \\
\hline 9. & $\begin{array}{l}\text { The assessment of professional } \\
\text { competence: building blocks for } \\
\text { theory development } \\
\text { C.P.M. van der Vleuten, , } \\
\text { Schuwirth, , F. Scheele, E.W. } \\
\text { Driessen, B. Hodges [12] }\end{array}$ & $\begin{array}{l}\text { Assessment of professional competence based on } \\
\text { Miller's pyramid, a distinction is made between } \\
\text { established assessment technology for assessing } \\
\text { 'knows', 'knowing how' and 'showing how' and } \\
\text { more recent developments in the assessment of } \\
\text { (clinical) performance at the 'does' level. }\end{array}$ & $\begin{array}{l}\text { Professional competence based } \\
\text { for assessing 'knows', } \\
\text { 'knowing how' and 'showing } \\
\text { how' - skills }\end{array}$ \\
\hline 10. & $\begin{array}{l}\text { A Personality-Competence Model } \\
\text { of Opinion } \\
\text { Timo Gnambs; [13] }\end{array}$ & $\begin{array}{l}\text { Results emphasize two major sources of domain- } \\
\text { specific opinion leadership (DSOL) which is related } \\
\text { to personal competence: personality in the form of a } \\
\text { general, domain-independent influencer trait and } \\
\text { competencies in terms of product-specific } \\
\text { knowledge; }\end{array}$ & $\begin{array}{l}\text { Leadership - which is related to } \\
\text { personal competence: } \\
\text { personality independent } \\
\text { influencer trait and } \\
\text { competencies in terms of } \\
\text { product-specific knowledge; }\end{array}$ \\
\hline 11. & $\begin{array}{l}\text { Digital competence - an emergent } \\
\text { boundary concept for policy and } \\
\text { educational research Minna } \\
\text { Lakka laLiisa Ilomäki Saami } \\
\text { Paavola Anna Kantosalo [14] }\end{array}$ & $\begin{array}{l}\text { Elements of competence - a variety of skills and } \\
\text { competences, and its scope is wide, as is its } \\
\text { background; }\end{array}$ & $\begin{array}{l}\text { Elements of competence - a } \\
\text { variety of skills }\end{array}$ \\
\hline 12. & $\begin{array}{l}\text { Concept of competence: A } \\
\text { conceptual clarification. Weinert, } \\
\text { Franz Emanuel }[15]\end{array}$ & $\begin{array}{l}\text { The concept of competence, mentioning specific } \\
\text { competencies including: economic, technological, } \\
\text { technical, and methodological competencies; social } \\
\text { competencies; creativity and innovation skills; and } \\
\text { mobility and flexibility combined with persistence, } \\
\text { reliability, and precision. }\end{array}$ & $\begin{array}{l}\text { The concept of competence } \\
\text { creativity and innovation skills; } \\
\text { and mobility and flexibility } \\
\text { combined with persistence, } \\
\text { reliability, and precision. }\end{array}$ \\
\hline 13 & $\begin{array}{l}\text { The Limits of Competence: } \\
\text { Knowledge, Higher Education and } \\
\text { Society. Barnett, Ronald [16] }\end{array}$ & $\begin{array}{l}\text { The competence focuses on some ideas either } \\
\text { disappearing from public debate or defunct as } \\
\text { apparently unworthy of serious attention, including } \\
\text { understanding, critical thought, interdisciplinary, and } \\
\text { wisdom. Two ideologies of competence---operational } \\
\text { and academic--against each other and sketches an } \\
\text { alternative definition of human being. This idea of } \\
\text { human being is relatively unconstrained by sectional } \\
\text { interests, contains a sense of knowing not derived } \\
\text { from mere instrumentality, and looks to promote } \\
\text { human beings in situations and conditions } \\
\text { unimaginable because the human beings concerned } \\
\text { will be doing the imagining. }\end{array}$ & $\begin{array}{l}\text { The competence focuses } \\
\text { critical thought, understanding, } \\
\text { interdisciplinary, and wisdom, } \\
\text { sense of knowing. }\end{array}$ \\
\hline 14. & $\begin{array}{l}\text { The skill element in decision } \\
\text { making under uncertainty: Control } \\
\text { or competence? Judgment and } \\
\text { Decision Making } \\
\text { Adam S. Goodie, Diana L. Young } \\
\text { [17] }\end{array}$ & $\begin{array}{l}\text { The competence elements control increased risk } \\
\text { taking markedly with all statistical properties held } \\
\text { constant, decisions made in domains of varying } \\
\text { difficulty, and by individuals of varying ability, } \\
\text { yielded further qualified support for the role of } \\
\text { competence. The role of control was replicated, and } \\
\text { participants' perceptions }\end{array}$ & $\begin{array}{l}\text { The competence elements } \\
\text { control varying difficulty, and } \\
\text { by individuals of varying } \\
\text { ability, yielded further qualified } \\
\text { support for the role of } \\
\text { competence. }\end{array}$ \\
\hline 15. & $\begin{array}{l}\text { Motivation reconsidered: The } \\
\text { concept of competence. } \\
\text { White, Robert W. [18] }\end{array}$ & $\begin{array}{l}\text { The new motivational concept of "competence" is } \\
\text { introduced indicating the biological significance of } \\
\text { such behavior. It furthers the learning process of } \\
\text { effective interaction with the environment. }\end{array}$ & $\begin{array}{l}\text { "competence" is introduced } \\
\text { indicating the biological } \\
\text { significance of such behavior } \\
\text { and further interaction with the } \\
\text { environment. }\end{array}$ \\
\hline
\end{tabular}


The main components of competence are knowledge, skills and capabilities. Unfortunately, the literature review showed only the presence of components of competencies, but it is not clear that proportional division and proportion. To understand the importance of each identified component, the authors used the results of three studies conducted in the framework of the EU projects in which one of the authors of the article took an active part.

Research results of three EU projects are included in this paper:

1) LLP Transfer of Innovation, Multilateral Projects, Leonardo da Vinci project "Employability and Skills Anticipation Policies: a Social ROI Approach" (thereafter - ESAP).

2) Erasmus+ KA 2 Cooperation for innovation and the exchange of good practices strategic partnership project „Coaches of SMEs: 5POINTS Trainings" (thereafter - 5POINTS)

3) Erasmus+ KA 2 Cooperation for innovation and the exchange of good practices strategic partnership project "Innovative strategic partnership for European higher education" (thereafter ISPEHE).

\section{Project: The 5POINTS}

Programme: The justification for the basic objectives of the project is explained by acting as coach to enable the SMEs to produce their own solutions and embed the understanding of innovative SMEs within their organizational structures.

Table 2.

Managerial Skills

\begin{tabular}{|c|c|c|c|c|c|}
\hline Areas & 章 & 害 & 莣 & 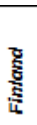 & $\frac{\pi}{3}$ \\
\hline $\begin{array}{l}\text { Self-awareness, self recognition, } \\
\text { entrepreneurship and leadership } \\
\text { skills (personal characteristics, value } \\
\text { priorities, time perspective, } \\
\text { resistance against stress, leading style } \\
\text { etc.) }\end{array}$ & 4 & 3 & 4 & 4 & 2 \\
\hline $\begin{array}{l}\text { Interpersonal relationships, } \\
\text { communication and specific } \\
\text { communication skills (written and } \\
\text { verbal presentation skills, managing } \\
\text { the meetings etc.) }\end{array}$ & 3 & 4 & 4 & 3 & 3 \\
\hline $\begin{array}{l}\text { Problem solving and effective } \\
\text { decision making skills }\end{array}$ & 5 & 4 & 3 & 3 & 4 \\
\hline $\begin{array}{l}\text { Negotiation and conflict management } \\
\text { skills }\end{array}$ & 4 & 5 & 3 & 4 & 4 \\
\hline
\end{tabular}

In the report published by the European Commission in 2012 regarding SMEs, it is indicated that SMEs play a key role in shaping European economy with a share of $98 \%$. 5POINT Coaches of SMEs: 5POINTS Trainings research and development and management of financial tools and developing problem solving abilities of SMEs, including the solution of financial problems, constitutes and important point which should be highlighted by the government as the public authority, as well as a vital issue which the academicians working in this area in universities should emphasize. This issue is taken as basis when determining the rationality of the project. The justification for the basic objectives of the project is explained by acting as coach to enable the SMEs to produce their own solutions and embed the understanding of innovative SMEs within their organizational structures[5].

\section{Project:}

Innovative Strategic Partnership For EU Higher Education. Programme:

Erasmus Plus Action KA2: Cooperation For Innovation And The Exchange Of Good Practices.

The main purpose of the Strategic Integration of Learning Modes (hereinafter SILM), as the first innovative project component, is to establish joint contemporary educational practices and produce a long-term strategic learning model based on the existing curricula adopted and successfully implemented in each partnering institution.

The Needs Assessment Analysis is the first element in preparing the SILM. The Needs Assessment presents an integrated report of the individually conducted analysis in each of the partnering institutions. The objectives of analysis are aligned with the specific objectives of SILM, and support their accomplishment. They are stated as follows:

- Identify the factual situation in each of the partnering HEIs

- Provide assistance for making needed decisions related to establishing optimal learning models and best practices

- Obtaining a participatory approach in constructing SILM from relevant stakeholders.

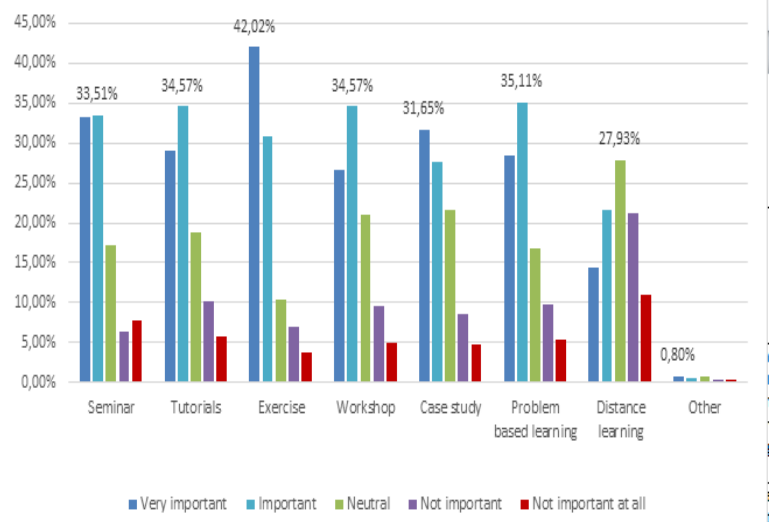

Fig. 1. Integrated results from all five partnering institutions.

Additional research shows that an important aspect of knowledge in their practical application, which require not only knowledge in its original form, but also skills. This conclusion discovers the importance of acquiring skills for students. 


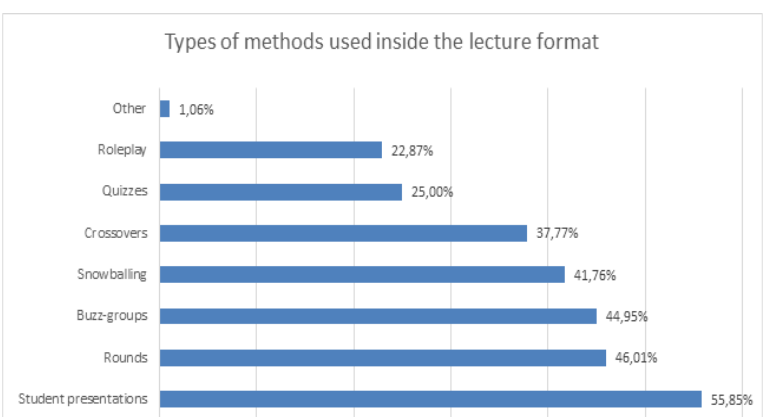

Fig. 2. Integrated results from all five partnering institutions.

The results of the research, students prefer the presentation and Buzz-groups that require the development of skills.

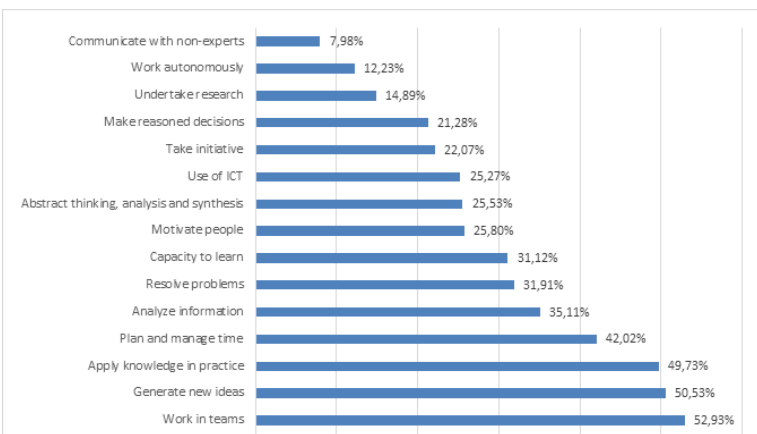

Fig. 3. Integrated results from all five partnering institutions.

The result of this study shows that it is necessary to improve quality skills such as: work in teams, apply knowledge in practice, generation of new ideas. Figure 3 shows areas of potential improvement of the students in order to get optimal use of the teaching methods utilized in classes. The areas of improvement, identified by the students for tackling in the future in order to optimize the utilization of teaching methods are: Working in teams with $52,93 \%$, followed by Generating new ideas with $50,53 \%$ and Applying the acquired knowledge in practice with $49,73 \%$. The areas whose improvement doesn't coincide with optimizing the teaching methods, by the students are: Communication with non-experts with 7,98\% and Working autonomously with $12,23 \%$.[6]

\section{Project}

The companies were asked about the abilities, skills and knowledge considered essential for the development of the current and future predictable jobs. They rated the importance of the proposed skills from 1 (not important) to 4 (very important).

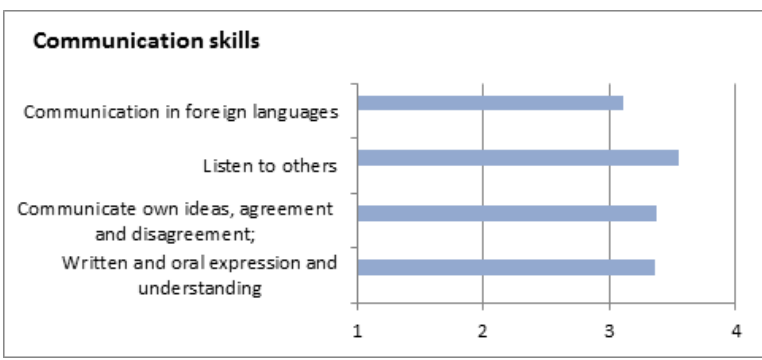

Fig. 4. Most valued Communication skills in all partnered countries.

The results of the researchrequire the development of skills. the results of the analysis of all three studies show the importance of two elements of competencies - skills and knowledge are inseparably linked, which in turn dominates the value of the skills[7].

To perform competence, skills and knowledge relationship autors of the paper used Kulkki \& Kosonen framework. Analyzing project researches projektov authors of the article think that Skills (S) based on Knowledge $(\mathrm{K})$ are main elements of $\mathrm{C}$ (competence). Due to the inseparable connection of knowledge and skills, underlined the value of dispersed and knowledge. Following the thoughts of Hayek and Tsoukas discusses the fact that knowledge is dispersed primarily because it is and individual procession. Although the stock of knowledge of the firm is a reflection of individuals' stock of knowledge, it is destined to stay dispersed and local because there are few means to control processes when knowledge is emerging all over the firm. Tsoukas declares that "rational economic calculation" cannot take into account the factual knowledge of the particular circumstances of time and space. [22]

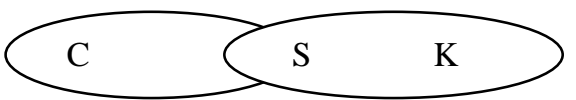

Fig. 5. Relationship of competence (C) and skills (S) based on knowledge (K) [done by authors based on $\mathrm{X}$ ]

\section{IV.CONCLUSION}

The authors of the paper conclude that the main dominant element of competence are knowledge and skills.

The results of the study the hypothesis was not confirmed at this stage. Triangulation showed the importance of knowledge and skills for competence creation. In turn, the factor of emotional intelligence has not been performed. This requires detailed indepth analysis, which will be revealed in future studies. Hypothesis: emotional intelligence influences the creation of competencies

As a first step of our research, there is not yet fully approved direct correlation between competence and emotional capital, and therefore authors are forced to use in future researches more detailed and deep analysis to get more information about explored problem. 


\section{V.ACKNOWLEDGMENTS}

This paper includes three different surveys results conducted by projects have been funded with support from the European Commission:

1) Erasmus+ Key Action 2 „Cooperation for innovation and the exchange of good practices" strategic Partnership project "Coaches of SMEs: 5POINTS Trainings”, Nr: 2014-1-TR01-KA202013033

2) Lifelong Learning Programme Transfer of Innovation, Multilateral Projects, Leonardo da Vinci project "Employability and Skills Anticipation Policies: a Social ROI Approach", Nr: 2011-1-PT1LEO05-08605.

3) Erasmus+ Key Action 2 „Cooperation for innovation and the exchange of good practices" strategic Partnership project "Innovative strategic partnership for European higher education", $\mathrm{Nr}$ : 2014-1-MK01-KA203-000275

This publication reflects the views only of the authors, and the European Commission cannot be held responsible for any use that may be made of the information contained therein.

\section{REFERENCES}

[1] Prahalad C. K., G.Hammel The Core of Competence , 2011, pp. 23-65.

[2] Lapina, I., Aramina, D.'Development of Human Capital based on Competencies and Quality of Education". Economics and Business. Vol.21, 2011, pp.60-66.

[3] Monnier, M, "Difficulties in Defining Social-Emotional Intelligence, Competences and Skills--A Theoretical Analysis and Structural Suggestion" International Journal for Research in Vocational Education and Training, v2 n1, 2015 p59-84

[4] Nicola S., Schutte, J, M. Malouff and Einar B. Thorsteinsson "Increasing Emotional Intelligence through Training: Current Status and Future Directions" International Journal of Emotional Education, Vol 5, Nr 1, April 2013 pp. 56.

[5] Bøtcher C and Andersen L.B, "Leading public service organizations: how to obtain high employee self-efficacy and organizational performance", Political Science, Public Management Review, vol 19.2017 pp 253-273
[6] Cantwell J, "Innovation and international business" vol.24 2017, pp 41-63

[7] Claudy M.C and Peterson M, "The Roles of Sustainability Orientation and Market Knowledge Competence in New Product Development Success", Journal of Product Innovation Management 33 (S1), 2016, pp 72-85.

[8] Ermilova E and Afsarmanesh H, "Competency modelling targeted on boosting configuration of virtual organisations" Production Planning and Control, The Management of Operations, vol.21, 2010 - Issue 2, pp 103-118

[9] Elliot A.J and Dweck C S., Handbook of Competence and Motivation, Gulford Press, NY, 2005, pp 92-114

[10]Foss N.J, Knudsen C, Towards a Competence Theory of the Firm, Routledge, 1996, pp 62-101

[11]Chamorro-Premuzic, T; Furnham, A., Personality and intellectual competence, Lawrence Erlbaum Associate, 2009

[12]C.P.M. van der Vleuten,, Schuwirth, Scheele F, E.W. Driessen, B. Hodges "The assessment of professional competence: building blocks for theory development ", Best Practice and Research, vol.24, Issue 6, Pages 703-719

[13]Gnambs T; A Personality-Competence Model of Opinion Minna L, Paavola I.S, Kantosalo A, "Digital competence an emergent boundary concept for policy and educational research", Education and Information Technologies May 2016, vol.21, Issue 3, pp 655-679

[14] Weinert F.E, Concept of competence: A conceptual clarification, Munich, Germany, 1999

[15]Ronald B, The Limits of Competence: Knowledge, Higher Education and Society. The Society for Research Into Higher Education and Open University Press; Reprint edition, 1999

[16] Goodie A. S. and Young D. L." The skill element in decision making under uncertainty: Control or competence? " Judgment and Decision Making , Judgment and Decision Making, vol. 2, No. 3, June 2007, pp183-211

[17]White, R.W. Motivation reconsidered: "The concept of competence". Journal: Psychological review, 1959/09

[18]Ganite K. Tuğba Uçma U. 5POINTS Coaches of SMEs: 5POINTS Trainings, Tech. Rep. Nr: 2014-1-TR01-KA202013033, 2014

[19]. ISPEHE, SILM Needs Assessment Analysis Tech. Rep 2014-1-MK01-KA203-000275, 2014

[20] "Employability and Skills Anticipation Policies: a Social ROI Approach”, Tech. Rep , Nr: 2011-1-PT1-LEO05-08605, 2011

[21]Kulkki S., Kosonen, M. How Tacit Knowledge Explains Organizational Renewal and Growth: the Case of Nokia. Managing Industrial Knowledge. Edited by Nonaka, I., Teece, D.2001.p.249. 